\section{Rooting Response of Seven Passion Fruit Species to Basal Application of Auxin}

\author{
Jenny B. Ryals ${ }^{1}$, Patricia R. Knight ${ }^{1}$, and Eric T. Stafne ${ }^{1}$
}

ADDITIONAL INDEX WORDS. 1-naphthaleneacetic acid, cuttings, IBA, indole-3butyric acid, K-NAA, NAA, Passiflora, propagation, semihardwood

SumMary. Production of passion fruit (Passiflora sp.) via cuttings is a way to eliminate genetic variation in the crop and also results in a faster establishment time. This could aid producers in increasing production efficiency while maintaining genetic lines. The objective of this research was to evaluate ease of rooting and determine the optimal auxin source for seven species of passion fruit. Semihardwood two-node cuttings were taken from the middle of the parent vine, and auxin treatments were applied to the basal end of the cutting. The cuttings were then stuck to a depth of 1 inch on 20 Aug. 2019. Treatments included three auxin sources and seven passion fruit species. Treatments were set up as a randomized complete block design blocking on species, with 10 single-plant replications per treatment. Data were collected $30 \mathrm{~d}$ after sticking cuttings and included percent rooted, total root number, average root length (of the three longest roots, measured in centimeters), root quality ( $0-5$ scale, with $0=$ dead and $5=$ healthy, vigorous root system), root dry weight (measured in grams), and percent callus. Results showed that passion fruit cuttings receiving a hormone treatment had significantly positive effects on rooting responses, such as increased number, length, quality, and dry weight of roots. Blue passionflower ( $P$. caerulea) was the only species in which hormone treatment did not increase rooting compared with the control. The use of hormone to aid in cutting propagation of passion fruit is recommended, depending on the species being propagated.

$\mathrm{I}$ $\mathrm{n}$ the United States, passion fruit (Passiflora sp.) production is slowly starting to take off. From 2012 to 2017 , respectively, the number of farms producing passion fruit more than doubled in number from 153 farms to 364 farms, with the total acreage increasing as well, from 125 acres to 209 acres (U.S. Department of Agriculture, 2020). Production of passion fruit is largely accomplished by propagation from seed. This

Received for publication 27 May 2020. Accepted for publication 9 Sept. 2020.

Published online 16 October 2020

${ }^{1}$ Coastal Research and Extension Center, Mississippi State University, South Branch Experiment Station, Highway 26, Poplarville, MS 39470

This project was founded through a Specific Cooperative Agreement between Mississippi State University and the U.S. Department of Agriculture (USDA), Agricultural Research Service, supported by the Mississippi Agricultural, Forestry and Experiment Station and Mississippi State University Extension Service. This material is based on work supported by the National Institute of Food and Agriculture, USDA, Hatch project under accession no. MIS-149192.

We thank Robert F. Gabella for providing us with the Illinois maypop plant material.

J.B.R. is the corresponding author. E-mail: j.ryals@ msstate.edu.

This is an open access article distributed under the $\mathrm{CC}$ BY-NC-ND license (https://creativecommons.org/ licenses/by-nc-nd/4.0/).

https://doi.org/10.21273/HORTTECH04660-20 method is easy, and the seeds are easily acquired when processing the fruit. However, there are some disadvantages to propagating from seed. Primary among them is a large amount of genetic variation seen in the progeny. Passion fruit is a crosspollinated plant; therefore, plants propagated from seed will not be "true to type." This will create variation (desirable or undesirable) in the fruit crop produced by these plants. Plants grown from seed are also more susceptible to soil-borne pathogens and poor germination (Almeida et al., 1991; Faleiro et al., 2019; Lima et al., 2019). Regardless of the issues, seed propagation is still the main method of passion fruit propagation in commercial production (Kishore et al., 2006). Asexual propagation, usually done by grafting and cuttings, is how to eliminate the genetic variation observed in seed propagation (Carvalho Pires et al., 2010; Chaves et al., 2004; Faleiro et al., 2019; Gurung et al., 2015; Miranda et al., 2009). These plants are clones and thus "true to type" to the stock plant from which the cutting or scion was taken. In comparison with grafting, propagation via cuttings has the advantage being less laborious (Salomao et al.,
2002). Cuttings have also been observed to be more uniform, more disease resistant, and more productive than plants propagated by seed (Davies et al., 2018; Junqueira et al., 2005; Lima et al., 2019). Propagation from cuttings can also reduce establishment time because the plant will not be starting from a seed. A seed will require extra time to germinate before it begins to grow, and may take more than 1 year before it begins producing fruit, whereas a cutting may produce fruit the same year it is propagated. Thus, if you begin propagating passion fruit from seed and cuttings at the same time, the cuttings will be established and producing fruit before the seeded plants.

Numerous passion fruit species produce fruit, but only a few are eaten by humans. Some of the consumable, fruit-bearing Passiflora species are from supersection Passiflora whereas a few others are in the supersection Laurifolia (Ulmer and MacDougal, 2004). Both types are represented in this study, as well as one species, blue passionflower ( $P$. caerulea), within supersection Stipulata, and another in Tacsonia, banana passion fruit $(P$. tripartita var. mollissima). Two passion fruit species native in the southeastern United States, maypop ( $P$. incarnata) and yellow passionflower (P. lutea), produce flowers, but their fruit is lacking in commercial potential. However, as the climate continues to warm, production of fruitproducing passion fruit species may be possible. With this in mind, understanding how various passion fruit species grow in a subtropical environment is paramount to determining whether viable production of these vines is feasible. One aspect of establishing a production area is making sure an ample supply of plant material is available; thus, defining the propagation requirements for each species becomes a basic, critical necessity. The objective of this research was to evaluate the effect of auxin sources on rooting for seven species of passion fruit.

\section{Materials and methods}

The seven passion fruit species chosen were banana passion fruit, blue passionflower, two maypops (one from Mississippi and one from Illinois), purple passion fruit (P.edulis f. edulis), yellow passion fruit ( $P$. 
edulis f. flavicarpa), sweet calabash ( $P$. maliformis), sweet granadilla $(P$. ligularis), and water lemon ( $P$. laurifolia).

Semihardwood, medial twonode cuttings were taken from parent vines of various ages and stuck to a depth of 1 inch on 20 Aug. 2019. Parent vines were grown both in pots and in the ground in both greenhouses and outdoors at Mississippi State University, South Mississippi Branch Experiment Station located in Poplarville (lat. $30^{\circ} 85^{\prime} 36^{\prime \prime} \mathrm{N}$, long. $89^{\circ} 49^{\prime} 94^{\prime \prime} \mathrm{W}$; elevation, $97 \mathrm{~m}$; U.S. Department of Agriculture hardiness zone, 8b). Parent vines were grown from seed, with the exception of the maypops, which were grown from cuttings. After receiving a 5-s basal quick-dip in the appropriate treatment auxin source, cuttings were placed in a growing mix (Jolly Gardner Pro-Line C/B; Old Castle Lawn \& Garden, Atlanta, GA) in 1.5-inch, six-cell tray inserts. The growing mix contains Canadian sphagnum peat, processed pine bark, coarse perlite, and medium vermiculite. The cuttings were placed in the greenhouse, where they were subjected to an average daytime temperature of 84.3 ${ }^{\circ} \mathrm{F}$, a dewpoint of $76.0^{\circ} \mathrm{F}$, and a relative humidity (RH) of $77.2 \%$. They also were subjected to an average nighttime temperature of $75.7^{\circ} \mathrm{F}$, a dewpoint of $74.5^{\circ} \mathrm{F}$, and an $\mathrm{RH}$ of $96.3 \%$. Cuttings received intermittent mist for $6 \mathrm{~s}$ every $10 \mathrm{~min}$ during daylight hours. No fertilizer was applied during this study. We measured photosynthetically active radiation $(P A R)$ using a temperature and light data collector (WatchDog 2400; Spectrum Technologies, Aurora, IL). Using the conversion equation provided by Torres and Lopez (2010), we determined the daily light integral (DLI) by multiplying $P A R$ by 0.0864 (i.e., the number of seconds in a day divided by one million). Our calculations showed the cuttings received an average of $41.171 \mathrm{~mol} \cdot \mathrm{m}^{-2} \cdot \mathrm{d}^{-1}$ DLI over the $30 \mathrm{~d}$.

Treatments included three auxin sources and seven passion fruit species. In previous studies, optimal auxin concentration and source have been observed to vary among species and experiments. Based on previous studies, positive rooting responses were observed in the passion fruit, resulting from both indole-3-butyric acid (IBA) and 1-naphthaleneacetic acid (NAA) treatments, and our auxin rates were selected based on these results (Carvalho Pires et al., 2010; Chaves et al., 2004; Gurung et al., 2015; Sabião, 2013).

Based on these results, we hypothesized that some species could require both IBA and NAA to reach optimal rooting; thus, we selected to use combination auxin treatments in this experiment. The three auxin sources were a control, $500 \mathrm{ppm}$ $\mathrm{IBA}+250$ ppm NAA (Dip'N Grow; Dip'N Grow, Clackamas, OR), and $1000 \mathrm{ppm} \mathrm{IBA} \mathrm{+} 250 \mathrm{ppm} \mathrm{1-}$ naphthaleneacetic acid, potassium salt (K-NAA) (Hortus IBA Water Soluble Salts; Phytotronics, Earth City, MO). The control was water only (i.e., 0 ppm IBA, 0 ppm NAA). We combined $1000 \mathrm{ppm}$ IBA with $250 \mathrm{ppm} \mathrm{K}$ NAA to see an increase in IBA rate while maintaining the NAA rate across treatments.

Treatments were set up as a randomized complete block design blocking on species, with 10 singleplant replications per treatment. Data were collected $30 \mathrm{~d}$ after sticking cuttings in growing mix and included percent rooted, total root number, length of three longest roots (measured in centimeters), root quality (visual rating of $0-5$ points, with $0=$ dead, no callus and $\mathbf{5}=$ healthy, vigorous root system), root dry weight (measured in grams), and percent callus (visual rating of whether callus was present). After visual ratings were taken, roots were detached from cuttings and placed in a $4.75 \times$ 11-inch paper envelope for drying. Root samples were then placed into a $60-{ }^{\circ} \mathrm{C}$ forced-air oven and dried overnight $(24 \mathrm{~h})$ to a constant weight. Dry weight was then recorded for each tissue type. Data were analyzed using PROC GLM, and means separation was determined using Tukey's honestly significant difference test at $P \leq 0.05$ in SAS (version 9.4; SAS Institute, Cary, NC).

\section{Results and discussion}

Blue PASSIONFLOWER. Root number $(\mathrm{n}=3, P=0.002)$, average root length $(2.9 \mathrm{~cm}, P=0.018)$, and root quality $(1.1, P=0.001)$ were all greater in control cuttings than cuttings treated with both auxin treatments (data not shown). No differences in any of the treatments were observed for root dry weight $(0.001 \mathrm{~g}, P=0.125)$, percent rooted $(20 \%, P=0.999)$, or percent callus $(20 \%, P=0.999)$ (data not shown).

Chaves et al. (2004) saw an increase in percent rooting of blue passionflower cuttings treated with $250,500,1000$, and $2000 \mathrm{ppm}$ NAA compared with no NAA. In contrast, Mayer et al. (2017) observed that, along with an increase of IBA concentration, the percentage mortality of blue passionflower cuttings increased. These results led them to conclude that auxin is not needed for the propagation of blue passionflower. The results from our experiment align similarly with those of Mayer et al. (2017) in that we also observed the death of cuttings exposed to auxin treatments in comparison with the control.

BANANA PASSION FRUIT. No roots formed in the cuttings of banana passion fruit for any treatment. Therefore, no data were collected for percent rooting, root number, average root length, and root dry weight. Although some cuttings were completely dead, others had callused, which could have led to the possible formation of roots, had the cuttings been left longer than $30 \mathrm{~d}$. No difference in treatments was observed for percent callus $(20 \%, P=0.221)$ (data not shown). As a result of callus being present, cuttings were not considered to be dead and a root quality rating was able to be collected. Root quality was observed to be greatest in the cuttings receiving the control treatment when compared with both auxin treatments $(0.5, P=0.010)$ (data not shown).

Purple passion Fruit. Root number $(\mathrm{n}=48, P<0.0001)$ and root dry weight $(0.099 \mathrm{~g}, P=0.021)$ was greatest in purple passion fruit cuttings when 1000 ppm IBA +250 ppm NAA was applied (Table 1 ). The number of roots were two to four times the number observed with the control or the $500 \mathrm{ppm} \mathrm{IBA}+250$ ppm NAA treatment. No differences in treatments were observed for average root length $(9.2 \mathrm{~cm}, P=0.253)$, root quality $(3.8, P=0.175)$ percent rooted $(100 \%, P=1.000)$, or percent callus $(100 \%, P=1.000)$ (Table 1$)$.

Gurung et al. (2015) reported purple passion fruit was observed to have better root characteristics when semihardwood cuttings were treated 
Table 1. Influence of auxin basal application on dry weight, rooting percentage, number of roots, average length of the three longest roots, root quality, and percent callus of passion fruit species within supersection Passiflora.

\begin{tabular}{|c|c|c|c|c|c|c|}
\hline Auxin treatment ${ }^{\mathrm{z}}$ & $\begin{array}{c}\text { Dry wt } \\
{\text { (g/root })^{y}}^{\text {g }}\end{array}$ & $\begin{array}{c}\text { Rooted } \\
\text { cuttings (\%) }\end{array}$ & $\begin{array}{c}\text { Roots } \\
\text { (no./cutting) }\end{array}$ & $\begin{array}{l}\text { Avg length of three } \\
\text { longest roots }(\mathrm{cm})^{y}\end{array}$ & $\begin{array}{l}\text { Root quality } \\
(1-5 \text { scale })^{x}\end{array}$ & $\begin{array}{l}\text { Callus } \\
(\%)^{\mathbf{w}}\end{array}$ \\
\hline \multicolumn{7}{|l|}{ Purple passion fruit } \\
\hline Control & $0.045 \mathrm{~b}^{\mathrm{v}}$ & $100 \mathrm{a}$ & $10 \mathrm{~b}$ & $8 \mathrm{a}$ & $3.3 \mathrm{a}$ & $100 \mathrm{a}$ \\
\hline $\begin{array}{l}500 \text { ppm IBA + } 250 \\
\text { ppm NAA }\end{array}$ & $0.053 \mathrm{ab}$ & $100 \mathrm{a}$ & $26 \mathrm{~b}$ & $8.5 \mathrm{a}$ & $3.6 \mathrm{a}$ & $100 \mathrm{a}$ \\
\hline $\begin{array}{l}1000 \text { ppm IBA }+250 \\
\text { ppm NAA }\end{array}$ & $0.099 \mathrm{a}$ & $100 \mathrm{a}$ & $48 \mathrm{a}$ & $11 \mathrm{a}$ & $4.4 \mathrm{a}$ & $100 \mathrm{a}$ \\
\hline \multicolumn{7}{|l|}{ Yellow passion fruit } \\
\hline Control & $0.069 \mathrm{~b}$ & $100 \mathrm{a}$ & $24 \mathrm{~b}$ & $10 \mathrm{ab}$ & $3.6 \mathrm{~b}$ & $100 \mathrm{a}$ \\
\hline $\begin{array}{l}500 \text { ppm IBA }+250 \\
\text { ppm NAA }\end{array}$ & $0.116 \mathrm{a}$ & $100 \mathrm{a}$ & $75 \mathrm{a}$ & $12 \mathrm{a}$ & $5.0 \mathrm{a}$ & $100 \mathrm{a}$ \\
\hline $\begin{array}{l}1000 \text { ppm IBA }+250 \\
\text { ppm NAA }\end{array}$ & $0.060 \mathrm{~b}$ & $100 \mathrm{a}$ & $58 \mathrm{a}$ & $8 \mathrm{~b}$ & $3.9 \mathrm{~b}$ & $100 \mathrm{a}$ \\
\hline $\begin{array}{l}500 \text { ppm IBA + } 250 \\
\text { ppm NAA }\end{array}$ & $0.015 \mathrm{a}$ & $80 \mathrm{a}$ & $18 \mathrm{a}$ & $6.5 \mathrm{a}$ & $2.2 \mathrm{a}$ & $80 \mathrm{a}$ \\
\hline $\begin{array}{l}1000 \text { ppm IBA }+250 \\
\text { ppm NAA }\end{array}$ & $0.005 \mathrm{a}$ & $30 \mathrm{a}$ & $6 \mathrm{~b}$ & $2 \mathrm{~b}$ & $0.7 \mathrm{~b}$ & $30 \mathrm{a}$ \\
\hline$P$ value & 0.096 & 0.123 & 0.006 & 0.019 & 0.018 & 0.123 \\
\hline \multicolumn{7}{|c|}{ Maypop (from Mississippi) } \\
\hline Control & $0.000 \mathrm{~b}$ & $10 \mathrm{~b}$ & $0 \mathrm{~b}$ & $0.5 \mathrm{~b}$ & $1.0 \mathrm{a}$ & $100 \mathrm{a}$ \\
\hline $\begin{array}{l}500 \text { ppm IBA + } 250 \\
\text { ppm NAA }\end{array}$ & $0.027 \mathrm{a}$ & $70 \mathrm{ab}$ & $21 \mathrm{a}$ & 5 a & $2.0 \mathrm{a}$ & $70 \mathrm{a}$ \\
\hline $\begin{array}{l}1000 \text { ppm IBA }+250 \\
\text { ppm NAA }\end{array}$ & $0.027 \mathrm{a}$ & $80 \mathrm{a}$ & $22 \mathrm{a}$ & 7 a & $2.2 \mathrm{a}$ & $80 \mathrm{a}$ \\
\hline$P$ value & 0.009 & 0.030 & 0.006 & 0.001 & 0.087 & 0.088 \\
\hline
\end{tabular}

with 250 ppm NAA. Our results were similar in that Gurung et al. (2015) observed $67 \%$ rooted, 21.9 roots, a $9.9-\mathrm{cm}$ root length, and $5.73 \%$ callus at 250 ppm NAA. We saw $100 \%$ rooting, 26 roots, a $8.5-\mathrm{cm}$ root length, and $100 \%$ callus for the 500 ppm IBA +250 ppm NAA treatment. No differences in control or treatments were noted, save for increased root numbers in the 1000 ppm IBA + 250 ppm NAA treatment in purple passion fruit (Table 1 ).

Yellow PASSION FRUIT. Average root length $(12 \mathrm{~cm}, P=0.016)$ was longer for yellow passion fruit when $500 \mathrm{ppm} \mathrm{IBA} \mathrm{+} 250 \mathrm{ppm} \mathrm{NAA} \mathrm{was}$ applied compared with $1000 \mathrm{ppm}$ IBA + 250 ppm NAA (Table 1). Root quality $(5, P=0.001)$ and root dry weight $(0.116 \mathrm{~g}, P=0.001)$ were greater when $500 \mathrm{ppm} \mathrm{IBA}+250$ ppm NAA was applied (Table 1). Root number $(\mathrm{n}=67, P=0.001)$ was two to three times greater in both auxin treatments than the control treatment (Table 1). No difference in treatments was observed for percent rooted $(100 \%, P=1.000)$ or percent callus $(100 \%, P=1.000)$ (Table 1).

Carvalho Pires et al. (2010) observed that yellow passion fruit had the best root formation when treated with $500 \mathrm{ppm}$ IBA. Our results also showed that cuttings treated with 500 ppm IBA + 250 ppm NAA had the best rooting responses compared with those receiving no auxin and 1000 ppm IBA + 250 ppm NAA. Our experiment resulted in $100 \%$ rooting for cuttings receiving 500 ppm IBA + 250 ppm NAA. Carvalho Pires et al. (2010) had $77.1 \%$ and $79.2 \%$ on two yellow passion fruit cultivars. Roncatto et al. (2008) and Salomao et al. (2002) both observed that the addition of an auxin treatment was not a significant factor in rooting yellow passion fruit cuttings. However, Roncatto et al. (2008) only observed rooting percentages of $21.7 \%$ to $23.3 \%$. Salomao et al. (2002) observed rooting percentages ranging from $69 \%$ to $96 \%$, depending on the stem location from which the cutting was taken.

MAYPOP (FROM IlLINOIS). Average root length $(6.5 \mathrm{~cm}, P=0.019)$ and root quality $(2.2, P=0.018)$ were greater when $500 \mathrm{ppm} \mathrm{IBA}+250$ ppm NAA was applied compared with 1000 ppm IBA + 250 ppm NAA (Table 1). Root number was three times greater in cuttings treated with 500 ppm IBA + 250 ppm NAA than cuttings treated with the control and $1000 \mathrm{ppm} \mathrm{IBA}+250 \mathrm{ppm} \mathrm{NAA}(\mathrm{n}=$ $18, P=0.006$ ) (Table 1 ). No differences between treatments were observed for root dry weight $(0.01 \mathrm{~g}$, $P=0.096)$, percent rooted $(70 \%, P=$ 
Table 2. Influence of auxin basal application on dry weight, rooting percentage, number of roots, average length of the three longest roots, root quality, and percent callus of passion fruit species within supersection Laurifolia.

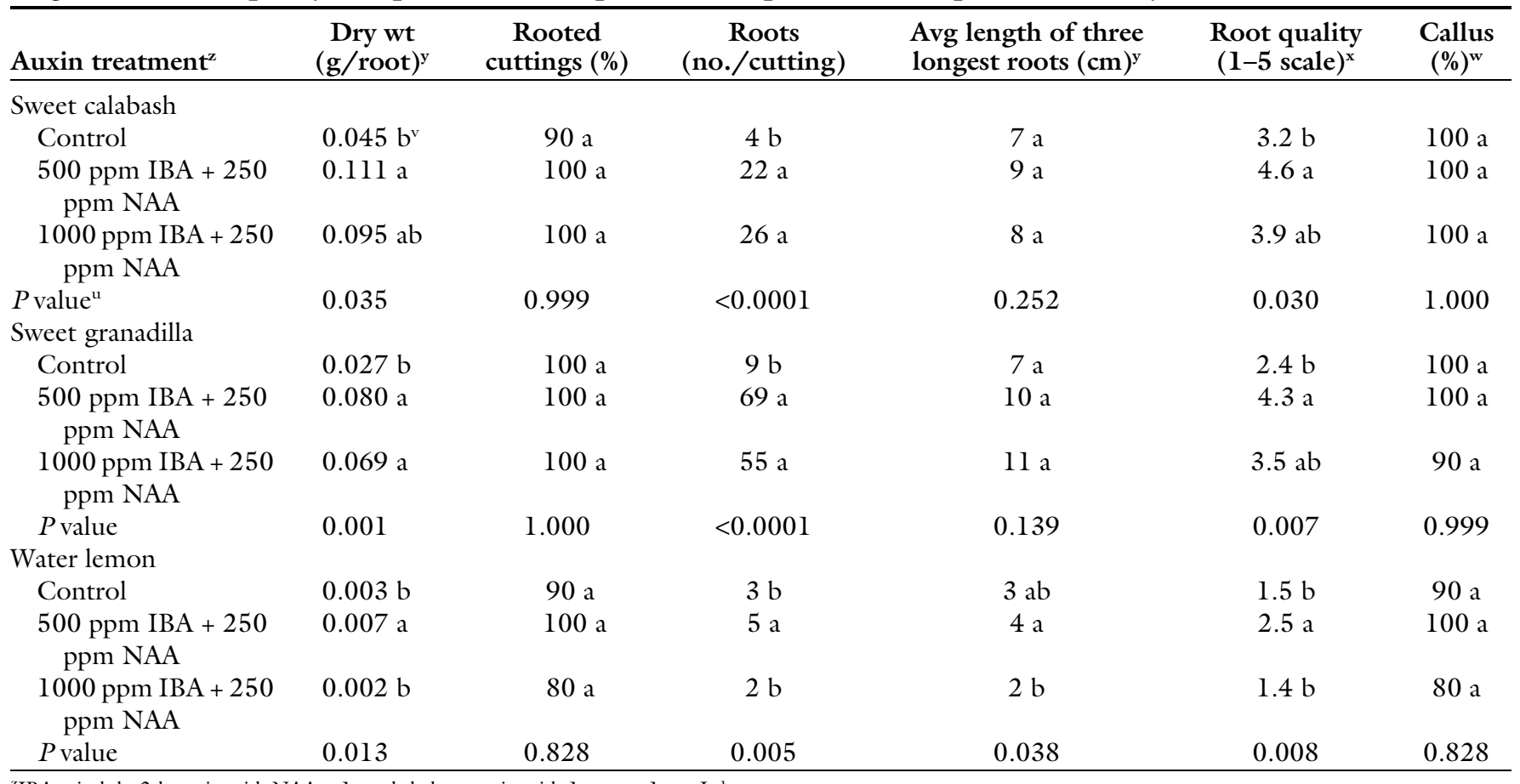

${ }^{\mathrm{z}} \mathrm{IBA}=$ indole-3-butyric acid; NAA $=1$-naphthaleneacetic acid. $1 \mathrm{ppm}=1 \mathrm{mg} \cdot \mathrm{L}^{-1}$.

${ }^{\mathrm{y}} \mathrm{l} \mathrm{g}=0.0353 \mathrm{oz}, 1 \mathrm{~cm}=0.3937$ inch.

${ }^{\mathrm{x}}$ Visual rating with $0=$ dead, no callus and $5=$ healthy, vigorous root system.

"Visual rating of whether roots or callus were present.

${ }^{\mathrm{v}}$ Means followed by the same letter are similar and not significantly different $(\alpha=0.05)$. Treatment means were not compared across species.

uProbability values for differences between means were obtained using Tukey's honestly significant difference test at $P \leq 0.05$.

$0.123)$, or percent callus $(70 \%, P=$ 0.123 ) (Table 1).

Maypop (FROM Mississippi). Root number $(\mathrm{n}=22, P=0.006)$, average root length $(6 \mathrm{~cm}, P=$ $0.001)$, and root dry weight $(0.027$ g, $P=0.009$ ) were all greater in cuttings treated with auxin than with the control treatment (Table 1). The root number was 20 times greater than the control, whereas the average root length was 12 times greater than the control. Percent rooted $(80 \%, P=$ $0.030)$ was greater in cuttings treated with 1000 ppm IBA + 250 ppm NAA than with the control treatment ( $\mathrm{Ta}$ ble 1). No differences between treatments were observed for root quality (1.7, $P=0.087$ ) and percent callus $(83 \%, P=0.088)$ (Table 1$)$.

Maypops are generally propagated by seed or root cuttings (Asch and Hart, 2004; Gilman, 2014; Vanderplank, 2000; Wehtje et al., 1985), but McGuire (1999) stated they could be propagated by shoot cuttings. Little research has been done to describe potential variation among maypop populations; thus, there could be undocumented differences in auxin tolerance.
Sweet calabash. Both auxin treatments resulted in five times more roots than the control treatment $(\mathrm{n}=$ $24, P<0.0001$ ) (Table 2 ). No difference in treatments was observed for average root length $(8 \mathrm{~cm}, P=0.252)$, percent rooted $(97 \%, P=0.999)$, or percent callus $(100 \%, P=1.000)$ (Table 2$)$. Dry weight $(0.111 \mathrm{~g}, P=$ $0.035)$ and root quality $(4.6, P=$ $0.030)$ were both greater in the 500 ppm IBA + 250 ppm NAA treatment than in the control, but did not differ from the $1000 \mathrm{ppm} \mathrm{IBA}+250 \mathrm{ppm}$ NAA treatment (Table 2).

SwEET GRANADILla. Root number $(\mathrm{n}=62, P<0.0001)$ and dry weight $(0.0745 \mathrm{~g}, P=0.001)$ were greater in both auxin treatments than in the control (Table 2). Root number was six to seven times greater with auxin treatments than in the control. No difference in treatments was observed for average root length (9.3 $\mathrm{cm}, P=0.139)$, percent rooted (100\%, $P=1.000)$, or percent callus (97\%, $P=0.999$ ) (Table 2). Root quality was greater in cuttings treated with 500 ppm IBA + 250 ppm NAA than cuttings treated with the control, but showed no difference to cuttings treated with 1000 ppm $\mathrm{IBA}+250$ ppm NAA $(P=0.007)$ (Table 2).

WATER LEMON. Root number (n $=5, P=0.005)$, root dry weight $(0.0007 \mathrm{~g}, P=0.013)$, and root quality $(2.5, P=0.008)$ were all greater in cuttings treated with 500 ppm IBA + 250 ppm NAA than in cuttings treated with the control or $1000 \mathrm{ppm} \mathrm{IBA}+250$ ppm NAA (Table 2). Average root length (4 cm, $P=0.038$ ) was greater than cuttings treated with 1000 ppm IBA + 250 ppm NAA but was not different from cuttings treated with the control (Table 2). No difference in treatments was observed for percent rooted $(90 \%, P=0.828)$ or percent callus $(90 \%, P=0.828)$ (Table 2$)$.

Water lemon had an increasing average number of roots when IBA concentrations increased from 0 , 1000 , 3000, to 5000 ppm (Sabião, 2013 ). In our study, water lemon was observed to have a decreasing number of roots when the IBA concentration was increased.

It is possible that some of the differences observed in our study compared with other studies could 
be the result of hormone sources. The hormone source used in our study contained both IBA + NAA, whereas the other research reviewed only used a single form of either auxin. The combination of auxin sources could have been the reason for some of the increases we saw in rooting responses in comparison with others. One study reported using IBA + NAA at a rate of $\approx 650 \mathrm{IBA}+352 \mathrm{NAA}$ to propagate three-node, semihardwood cuttings of tree passionflower $[P$. lindeniana (Hilgenhof, 2012)] successfully. However, little research has been done using combination auxin sources in passion fruit cutting propagation.

Based on these results, sweet calabash, water lemon, purple passion fruit, yellow passion fruit, sweet granadilla, and maypop from Mississippi all resulted in better rooting responses when cuttings were dipped basally in auxin compared with cuttings that were not. Blue passionflower performed better when cuttings were not treated with auxin. Maypop from Illinois performed the same overall, regardless of the use of auxin or no auxin. Banana passion fruit did not perform well in this trial; it is possible that this species may need additional time to form roots than the 30-d limitation set in our study.

\section{Literature cited}

Almeida, L.D., M.A.C. Boaretto, R.D. Santana, G.D. Nascimento, P.J. Souza, and A.R.S. José. 1991. Estaquia e comportamento de maracujazeiros (Passiflora edulis SIMS f. flavicarpa Deg.) propagados por vias sexual e vegetativa. Rev. Bras. Frutic. 13:153-156.

Asch, D.L. and J.P. Hart. 2004. Crop domestication in prehistoric eastern North America, p. 314-319. In: Encyclopaedia of plant crop science. Marcel Dekker, New York, NY.

Carvalho Pires, M., J.R. Peixoto, and O.K. Yamanishi. 2010. Rooting of pas- sion fruit species with indole-3-butyric acid under intermittent misting conditions. Acta Hort. 894:177-183.

Chaves, R.D.C., N.T.V. Junqueira, I. Manica, J.R. Peixoto, A.V. Pereira, and J.D.F. Fialho. 2004. Enxertia de maracujazeiro-azedo em estacas herbáceas enraizadas de espécies de passifloras nativas. Rev. Bras. Frutic. 26:120-123.

Davies, F.T., Jr., R.L. Geneve, S.B. Wilson, H.T. Hartmann, and D.E. Kester. 2018. Hartmann and Kester's plant propagation: Principles and practices. 9th ed. Pearson Education, New York, NY.

Faleiro, F.G., N.T.V. Junqueira, T.G. Junghans, O.N. de Jesus, D. Miranda, and W.C. Otoni. 2019. Advances in passion fruit (Passiflora spp.) propagation. Rev. Bras. Frutic. 41:1-17.

Gilman, E.F. 2014. Passiflora incarnata wild passionflower, maypop. Univ. Florida IFAS Ext. FPS457.

Gurung, N., G.S.K. Swamy, and S.K. Sarkar. 2015. Rooting response of passion fruit cuttings under mist house and closed media sachet (CMS). Environ. Ecol. 33:1019-1021.

Hilgenhof, R. 2012. Passiflora subg. Astrophea: Curiosities amongst the passionflowers. Diss., Kew Diploma Horticulture, Royal Botanic Gardens, Kew, UK.

Junqueira, N.T.V., M.F. Braga, F.G. Faleiro, J.R. Peixoto, and L.C. Bernacci. 2005. Potential of wild passionfruit species as sources of disease resistance, p. 80108. In: F.G. Faleiro, N.T.V Junqueira, and M.F. Braga (eds.). Passionfruit: Germplasm and breeding. Embrapa Cerrados, Planaltina, Brazil.

Kishore, K., K.A. Pathak, D.S. Yadav, K.M. Bujarbaruah, R. Bharali, and R. Shukla. 2006. Passion Fruit Tech. Bul. 24.

Lima, L.K.S., O.N. de Jesus, T.L. Soares, S.A.S. de Oliveira, F. Haddad, and E.A. Girardi. 2019. Water deficit increases the susceptibility of yellow passion fruit seedlings to fusarium wilt in controlled conditions. Scientia Hort. 243:609-621.

Mayer, L., J. Meneghini, C.S. Fior, and E.M. de Freitas. 2017. Propagação de
Passiflora caerulea L. por estaquia. Iheringia Ser. Bot. 72:5-8.

McGuire, C.M. 1999. Passiflora incarnata (Passifloraceae): A new fruit crop. Econ. Bot. 53:161-176.

Miranda, D., M. Perea, and S. Magnitskiy. 2009. Propagación de especies pasifloráceas, p. 69-96. In: D. Miranda, G. Fischer, C. Carranza, S. Magnitskiy, F. Casierra-Posada, W. Piedrahíta, and L.E. Flórez (eds.). Cultivo, poscosecha y comercialización de las pasifloráceas en Colombia: Maracuyá, granadilla, gulupa y curuba. Colombian Society of Horticultural Science, Bogotá, Colombia.

Roncatto, G., G.C. Nogueira Filho, C. Ruggiero, J.C.D. Oliveira, and A.B.G. Martins. 2008. Enraizamento de estacas de espécies de maracujazeiro (Passiflora spp.) no inverno e no verão. Rev. Bras. Frutic. 30:1089-1093.

Sabião, R.R. 2013. Avaliação de progênies interespecíficas de maracujazeiro e estaquia de espécies potenciais como porta-enxerto. MS Thesis, Universidade Estadual Paulista Júlio de Mesquita Filho, Sao Paulo, Brazil.

Salomao, L.C.C., W.E. Pereira, R.C.C. Duarte, and D.L.D. Siqueira. 2002. Propagação por estaquia dos maracujazeiros doce (Passiflora alata Dryand.) e amarelo (P. edulis f. flavicarpa O. Deg.). Rev. Bras. Frutic. 24:163-167.

Torres, A.P. and R.G. Lopez. 2010. Measuring daily light integral in a greenhouse. Purdue Ext. Bul. HO-238-W.

Ulmer, T. and J.M. MacDougal. 2004. Passiflora: Passionflowers of the world. Timber Press, Portland, OR.

U.S. Department of Agriculture. 2020. NASS data and statistics. 20 May 2020. <http://www.nass.usda.gov/Data_and_ Statistics/Quick_Stats/index.asp>.

Vanderplank, J. 2000. Passion flowers. 3rd ed. MIT Press, Cambridge, MA.

Wehtje, G., R.B. Reed, and R.R. Dute. 1985. Reproductive biology and herbicidal sensitivity of maypop passionflower (Passiflora incarnata). Weed Sci. 33:484490. 